\title{
HALAL CERTIFICATION VALUE CHAIN IN BRUNEI DARUSSALAM
}

\author{
Nor Surilawana Sulaiman ${ }^{1}$, Norkhairiah Hashim² \\ Halalan Thayyiban Research Centre, Universiti Islam Sultan Sharif Ali, \\ Brunei Darussalam \\ surilawana.sulaiman@gmail.com $^{1}$
}

\begin{abstract}
As Brunei Darussalam is positioning itself to be a halal hub, Brunei needs to act fast to strengthen its halal certification value-chain or system. Therefore, the Brunei Government appointed Bahagian Kawalan Makanan Halal (Halal Food Control Division), Jabatan Hal Ehwal Syariah (Department of Shariah Affairs), as a body to handle the halal certification process. Due to the rapid growth of the halal industry both local and international, it is important to research the halal certification process.

The main objective of this study is to provide an understanding of the halal certification process in Brunei Darussalam. The study will highlight and determine to examine (1) the halal certification process, (2) actors, and (3) information on halal. The method used in this study is derived from the literature review in the form of related articles, journals, proceedings and books, and interviews with related actors of the halal certification.

The results of the study will reveal (1) the halal certification value chain, (2) the related agencies and acts of the halal certification process, and (3) the information required in applying halal certification in Brunei Darussalam.
\end{abstract}

Keywords: Halal Certification Process, V alue Chain, Halal Certification Documentation, Bahagian Kawalan Makanan Halal.

\section{Introduction}

Halal certification, as defined by Riaz \& Chaudry (2004), is a document issued by an Islamic organization confirming that the products listed on it comply with Shariah laws or guidelines as specified by the certifying agency, and halal certification can take the form of logo, marking, stamp, seal, or certification. Ab. Rahman supported this argument by saying that halal certification is one technique to identify and show that the products are halal (Ab. Rahman, n.d.). In other terms, a halal certificate is a proof of one's claim to be a halal products or distributor. For instance, it is a symbol of assurance and confidence in the eyes of customers, and food halal certificate holders may find that the certificate could boost up the marketability of their products. As halal certificates could become a global halal brand 
for quality affirmation, many Muslim and non-Muslim countries are using this chance to develop their own halal concerns, halal certification process, laws, and regulations (Asa, 2019). Therefore, every country to strengthen its halal certification value chain especially Brunei Darussalam since it positioning itself to be a halal hub in order to gain trust from people. For that reason, this article discusses the halal certification value chain of Brunei Darussalam for the purpose of the development of halal certification vis-à-vis their legal systems.

\section{Literature Review}

This study was based on the literature review of related publications, journals, conference proceedings, books, newspapers, brochures, and related authority websites to acquire a better understanding of Brunei Darussalam's halal certification process. The literature review of the halal certification process in Brunei Darussalam is summarized in Table 1 below.

Table 1

Halal Certification Process in Brunei Darussalam Literature Review

\begin{tabular}{|c|c|c|}
\hline Category & Descriptions & Sources \\
\hline \multirow{5}{*}{$\begin{array}{l}\text { Halal } \\
\text { Governing } \\
\text { Laws }\end{array}$} & $\begin{array}{l}\text { Manual Procedure of Halal } \\
\text { Certification }\end{array}$ & Saidpudin, et al. (2015) \\
\hline & Guideline for Halal Certification & Asa, (2019) \\
\hline & $\begin{array}{l}\text { Halal Meat Act / Halal Meat Act } \\
\text { Rules, } 2008\end{array}$ & Asa, (2019); Mohd Raffi (2020) \\
\hline & $\begin{array}{l}\text { Halal Certificate and Halal Label } \\
\text { Order, } 2005\end{array}$ & Asa, (2019) \\
\hline & $\begin{array}{l}\text { Standard for Halal Food (PBD } \\
\text { 24:2007) }\end{array}$ & Asa, (2019); Mohd Raffi (2020) \\
\hline \multirow{5}{*}{$\begin{array}{l}\text { Halal } \\
\text { Certification } \\
\text { Process }\end{array}$} & $\begin{array}{l}\text { Halal Certificate and Halal Label } \\
\text { (Amendment) Order of } 2017\end{array}$ & $\begin{array}{l}\text { Haji Sulaiman (2018); Haji Kifli (2019); Haji } \\
\text { Sulaiman, (2019) }\end{array}$ \\
\hline & $\begin{array}{l}\text { Halal Certification Process / } \\
\text { Procedure }\end{array}$ & $\begin{array}{l}\text { Haji Abdul Rahman (2009); Othman, et al. } \\
\text { (2015); Saidpudin, et al. (2015); Haji Sulaiman } \\
\text { (2019); Haji Sulaiman (2018); Mohd Raffi } \\
\text { (2020) }\end{array}$ \\
\hline & Halal Label & $\begin{array}{l}\text { Haji Abdul Rahman (2009); Othman, et al. } \\
\text { (2015); Mohd Raffi (2020) }\end{array}$ \\
\hline & Surveillance, Audit and Enforcement & $\begin{array}{l}\text { Haji Abdul Rahman (2009); Othman, et al. } \\
\text { (2015); Haji Sulaiman (2018) }\end{array}$ \\
\hline & Oral Test for Halal Food Supervisors & Haji Abdul Rahman (2009) \\
\hline Halal Authority & $\begin{array}{l}\text { Bahagian Kawalan Makanan Halal, } \\
\text { Majlis Ugama Islam Brunei }\end{array}$ & $\begin{array}{l}\text { Saidpudin, et al. (2015); Asa, (2019); Haji Kifli } \\
\text { (2019); Haji Sulaiman (2018); Haji Sulaiman, } \\
\text { (2019); Mohd Raffi (2020) }\end{array}$ \\
\hline Halal Issues & Challenges in Halal Industry & Othman, et al. (2015) \\
\hline
\end{tabular}




\section{Data Collection}

The main objective of this study is to provide an understanding of the halal certification process in Brunei Darussalam. The study will highlight and determine to examine (1) the halal certification process, (2) actors involved in the halal certification process, and (3) information flows in the halal certification process.

The method used in this study was derived from the literature review of related publications, journals, proceedings, and books in order to obtain a better understanding of Brunei Darussalam's halal certification process.

In addition, interviews with halal certification's associated players undertaken. In this study, the open-ended questions were utilized which allows respondents to answer the questions in their own terms and express their opinions and knowledge that are relevant to the questions asked without feeling pressed. The questions in this study were adapted from Noordin, Md Noor, Hashim, \& Samicho, (2009) and Noordin, Md Noor, \& Samicho, (2014). Table 2 lists the questions that were asked during the interview.

\section{Table 2 Interview Questions for Respondents}

\begin{tabular}{|c|c|c|}
\hline Dimensions & Questions & Sources/Adapted from \\
\hline \multirow{6}{*}{ Process } & $\begin{array}{l}\text { - What are the primary resources of halal } \\
\text { certification? }\end{array}$ & $\begin{array}{l}\text { Noordin, Md Noor, Hashim, \& } \\
\text { Samicho, (2009) }\end{array}$ \\
\hline & $\begin{array}{l}\text { - How long the duration to process the } \\
\text { halal certification application? }\end{array}$ & $\begin{array}{l}\text { Noordin, Md Noor, Hashim, \& } \\
\text { Samicho, (2009) }\end{array}$ \\
\hline & - How the halal certification is conducted? & Noordin, Md Noor , \& Samicho, (2014) \\
\hline & $\begin{array}{l}\text { - What technology used in the halal } \\
\text { certification? }\end{array}$ & $\begin{array}{l}\text { Noordin, Md Noor, Hashim, \& } \\
\text { Samicho, (2009) }\end{array}$ \\
\hline & $\begin{array}{l}\text { - How the technology supports the halal } \\
\text { certification process? }\end{array}$ & Noordin, Md Noor , \& Samicho, (2014) \\
\hline & $\begin{array}{l}\text { - What are the problems faced during the } \\
\text { process of halal certification? }\end{array}$ & $\begin{array}{l}\text { Noordin, Md Noor, Hashim, \& } \\
\text { Samicho, (2009) }\end{array}$ \\
\hline \multirow{3}{*}{ Actors } & $\begin{array}{l}\text { - What agencies involved in the halal } \\
\text { certification? }\end{array}$ & Noordin, Md Noor , \& Samicho, (2014) \\
\hline & $\begin{array}{l}\text { - Who are involved in the halal certification } \\
\text { process? }\end{array}$ & $\begin{array}{l}\text { Noordin, Md Noor, Hashim, \& } \\
\text { Samicho, (2009); Noordin, Md Noor, \& } \\
\text { Samicho, (2014) }\end{array}$ \\
\hline & $\begin{array}{l}\text { - What are their roles in the halal } \\
\text { certification process? }\end{array}$ & $\begin{array}{l}\text { Noordin, Md Noor, Hashim, \& } \\
\text { Samicho, (2009) }\end{array}$ \\
\hline \multirow{4}{*}{ Information } & $\begin{array}{l}\text { - What information that is requires in the } \\
\text { halal certification? }\end{array}$ & Noordin, Md Noor , \& Samicho, (2014) \\
\hline & $\begin{array}{l}\text { - Which information is important in the } \\
\text { halal certification? }\end{array}$ & Noordin, Md Noor , \& Samicho, (2014) \\
\hline & $\begin{array}{l}\text { - How the information affect the halal } \\
\text { certification decision making? }\end{array}$ & Noordin, Md Noor , \& Samicho, (2014) \\
\hline & $\begin{array}{l}\text { - Is there any agency's information system } \\
\text { that is integrated with the halal } \\
\text { information system? }\end{array}$ & Noordin, Md Noor , \& Samicho, (2014) \\
\hline
\end{tabular}




\section{Discussion and Findings}

Based on the literature review and interviews with the experts, the value chain of halal certification along the issues of the halal certification process was identified. The study's findings revealed (1) the halal certification value chain, (2) the related agencies and acts of the halal certification process, and (3) the information required in applying halal certification in Brunei Darussalam, all of which are important in the development of the halal value chain. The findings are discussed in the following sub-headings.

\section{Halal Certification related agencies and acts in Brunei}

In Brunei Darussalam, halal certification and the halal label is performed solely by the officers of the Bahagian Kawalan Makanan Halal (BKMH)/ Halal Food Control Division starting from application to site auditing to certification and follow-up audit (Haji Kifli, 2019). BKMH manages the halal certification procedures as a secretariat. Meanwhile, several government agencies have been designated as auditors under Chapter 18 of the Halal Certificate and Halal Label Order. As stated in Table 3, there were also related acts and standards that had to be followed in order to obtain a halal certificate.

Table 3

Related Agencies and Acts in Brunei Darussalam

\begin{tabular}{|c|c|c|}
\hline Agency & Functions & Acts \\
\hline $\begin{array}{l}\text { Majlis Ugama Islam Brunei } \\
\text { (MUIB) / Brunei Islamic } \\
\text { Religious Council, Ministry of } \\
\text { Religious Affairs }\end{array}$ & $\begin{array}{l}\text { Chief authority pertaining to } \\
\text { Islamic matters }\end{array}$ & $\begin{array}{l}\text { - Islamic Religious Council Act } \\
\text { and Kadis Court Cap } 77\end{array}$ \\
\hline $\begin{array}{l}\text { State Mufti's Office, Prime } \\
\text { Minister's Office }\end{array}$ & $\begin{array}{l}\text { Provide fatwa and shariah } \\
\text { matters }\end{array}$ & $\begin{array}{l}\text { - Islamic Religious Council Act } \\
\text { and Kadis Court Cap } 77\end{array}$ \\
\hline $\begin{array}{l}\text { Halal Food Control Division, } \\
\text { Department of Syariah Affairs, } \\
\text { Ministry of Religious Affairs }\end{array}$ & $\begin{array}{l}\text { - Monitoring and issues halal } \\
\text { certificate } \\
\text { - Provide enhancing } \\
\text { programme }\end{array}$ & $\begin{array}{l}\text { - } \text { BCG } 1 \text { - Guideline for Halal } \\
\text { Certification } \\
\text { - BCG } 2 \text { - Guideline for Halal } \\
\text { Compliance Audit } \\
\text { - BCG } 3 \text { - Guideline for Halal } \\
\text { Compliance Auditor } \\
\text { - BCG } 4 \text { - Guideline for Halal } \\
\text { Surveillance Audit }\end{array}$ \\
\hline $\begin{array}{l}\text { Islamic Legal Unit, Ministry of } \\
\text { Religious Affairs }\end{array}$ & $\begin{array}{l}\text { Enforment related halal } \\
\text { matters }\end{array}$ & \\
\hline $\begin{array}{l}\text { Department of Agriculture and } \\
\text { Agrifood, Ministry of Primary } \\
\text { Resources and Tourism }\end{array}$ & $\begin{array}{l}\text { - Provides nutrional } \\
\text { information } \\
\text { - Issues veterinary health } \\
\text { certificate }\end{array}$ & $\begin{array}{l}\text { - CAP } 183 \text { S 30/1998 - Halal } \\
\text { Meat Act, } \\
\text { - CAP. 183, R1 S 20/1999 - } \\
\text { Halal Meat Rules } \\
\text { - CAP.183 B.L.R.O. 3/2014 - } \\
\text { Halal Meat Act } \\
\text { - CAP } 183 \text { S21/2016 - Halal } \\
\text { Meat (Amendment) Rules, } \\
2016\end{array}$ \\
\hline
\end{tabular}




\begin{tabular}{|c|c|c|}
\hline & & $\begin{array}{l}\text { - PBD 27:2016 - Brunei } \\
\text { Standard for Organic } \\
\text { Agriculture (Vegetables and } \\
\text { Fruits) } \\
\text { - PBD 30:2016 - Crackers from } \\
\text { Marine and Freshwater Fish, } \\
\text { Crustacan and Molluscan } \\
\text { Shellfish }\end{array}$ \\
\hline $\begin{array}{l}\text { Food Safety \& Quality Control } \\
\text { Division, Ministry of Health }\end{array}$ & $\begin{array}{l}\text { - Provides food safety } \\
\text { programme } \\
\text { - Issues import permit }\end{array}$ & $\begin{array}{l}\text { - CAP. } 182 \text { S17/1998 - Public } \\
\text { Health (Food) Act } \\
\text { - CAP. 182, Rg } 1-\text { Public } \\
\text { Health (Food) Act, Public } \\
\text { Health (Food) Regulations } \\
\text { - S 27/01 - Public Health } \\
\text { (Food) Regulations. } 2001 \\
\text { - CAP 182 S006/2013 - Piblic } \\
\text { Health (Food) (Amendment) } \\
\text { Regulations, 2013 }\end{array}$ \\
\hline $\begin{array}{l}\text { National Standards Centre, } \\
\text { Prime Minister's Office }\end{array}$ & $\begin{array}{l}\text { Provide standards related with } \\
\text { halal }\end{array}$ & $\begin{array}{l}\text { - PBD 24:2007 - Brunei } \\
\text { Darussalam Standard for Halal } \\
\text { Food } \\
\text { - GD 24:2010 - Brunei } \\
\text { Darussalam Guidelines for } \\
\text { Manufacturing and Handling } \\
\text { of Halal Medicinal Products, } \\
\text { Traditional Medicines and } \\
\text { Health Supplements } \\
\text { - PBD 26:2016 - Brunei } \\
\text { Darussalam Guidelines for } \\
\text { Manufacturing and Handling } \\
\text { of Halal Cosmetics }\end{array}$ \\
\hline Local Universities & $\begin{array}{l}\text { - Provide R\&D and courses in } \\
\text { halal matters }\end{array}$ & Not Introduced \\
\hline $\begin{array}{l}\text { Attorney General's Chamber, } \\
\text { Prime Minister's Office }\end{array}$ & $\begin{array}{l}\text { - Provide enforment law and } \\
\text { order }\end{array}$ & $\begin{array}{l}\text { - Halal Certificate and Halal } \\
\text { Label Order, } 2005 \\
\text { - Halal Certificate and Halal } \\
\text { Label Order, } \\
\text { (Amendment) }\end{array}$ \\
\hline $\begin{array}{l}\text { Royal Brunei Custom and } \\
\text { Excise Department, Ministry of } \\
\text { Finance and Economy }\end{array}$ & $\begin{array}{l}\text { - Issuance of import and } \\
\text { export activity }\end{array}$ & \\
\hline
\end{tabular}

\section{Halal Certification Value Chain}

Porter (1985) defined the value chain as a systematic way to divide a firm into its discrete operations that may be used to investigate how the activities in a firm are and could be grouped. The value chain of halal certification in Brunei Darussalam can be examined 
in this study by looking at three elements: (1) processes, (2) actors, and (3) information. The correlation between these variables is critical for identifying operational concerns.

\section{Processes}

In Brunei Darussalam, application for the halal certificate is made mandatory for food company owners, whereas non-food products such as medicines, cosmetics, consumable goods, and services are only need to apply on a voluntary basis.

The applicants who wish to apply for a halal certificate must go through BKMH who is given the power of handling the process of halal certification while MUIB ultimately will be the last to give approval (Haji Sulaiman, 2020) or rejection.

First, the applicants may obtain the application form from the Ministry of Religious Affairs

website, http://www.kheu.gov.bn/SitePages/Muat\%20Turun\%20Borang\%20Permohonan.aspx, or applicants can get it from the BKMH counter. Then, submit the form to BKMH at the counter.

Upon receiving the application form, the BKMH will conduct the oral and written tests for Halal Food Supervisors of the applicant's company. Once pass both tests, then Halal Certification and Halal Label Inspection Committee (hereafter referred to as Inspection Committee) comprised of MoRA, Ministry of Primary Resources and Tourism (MPRT), and Ministry of Health $(\mathrm{MoH})$ will go through an adequacy audit which conducted once a week. The Inspection Committee will review the completed form and if they are satisfied, they will ask the Chief Inspector and the Auditor to do the on-site audit by inspecting the premises or producer.

The applicant's premises are next onspected and supervised by the Chief Inspector and Auditor, as well as their staff. The audit team will next write a report for the Inspection Committee, which will ultimately be forwarded to MUIB. MUIB will make the final decision, whether to approve or reject the application.

Finally, once payments have been received, a Halal Certificate for the premises will be issued if it is supported. Applicants who are approved will be asked to pay to BND 90 to MUIB for each halal certificate that would be valid for three years. It takes 45 days from the start of halal certification process to the issuance of halal certificate.

In addition, a surveillance audit will be done at any moment to ensure that the premises always in compliance with the halal food standards requirements. The halal certificate will be revoked if the premises were caught to have committed an offense. The flowchart of overall halal certification processes is depicted in Figure 1 below. 
FLOW CHART FOR APPLICATION OF HALAL CERTIFICATE

[HALAL CERTIFICATE AND HALAL LABEL ORDER , 2005]

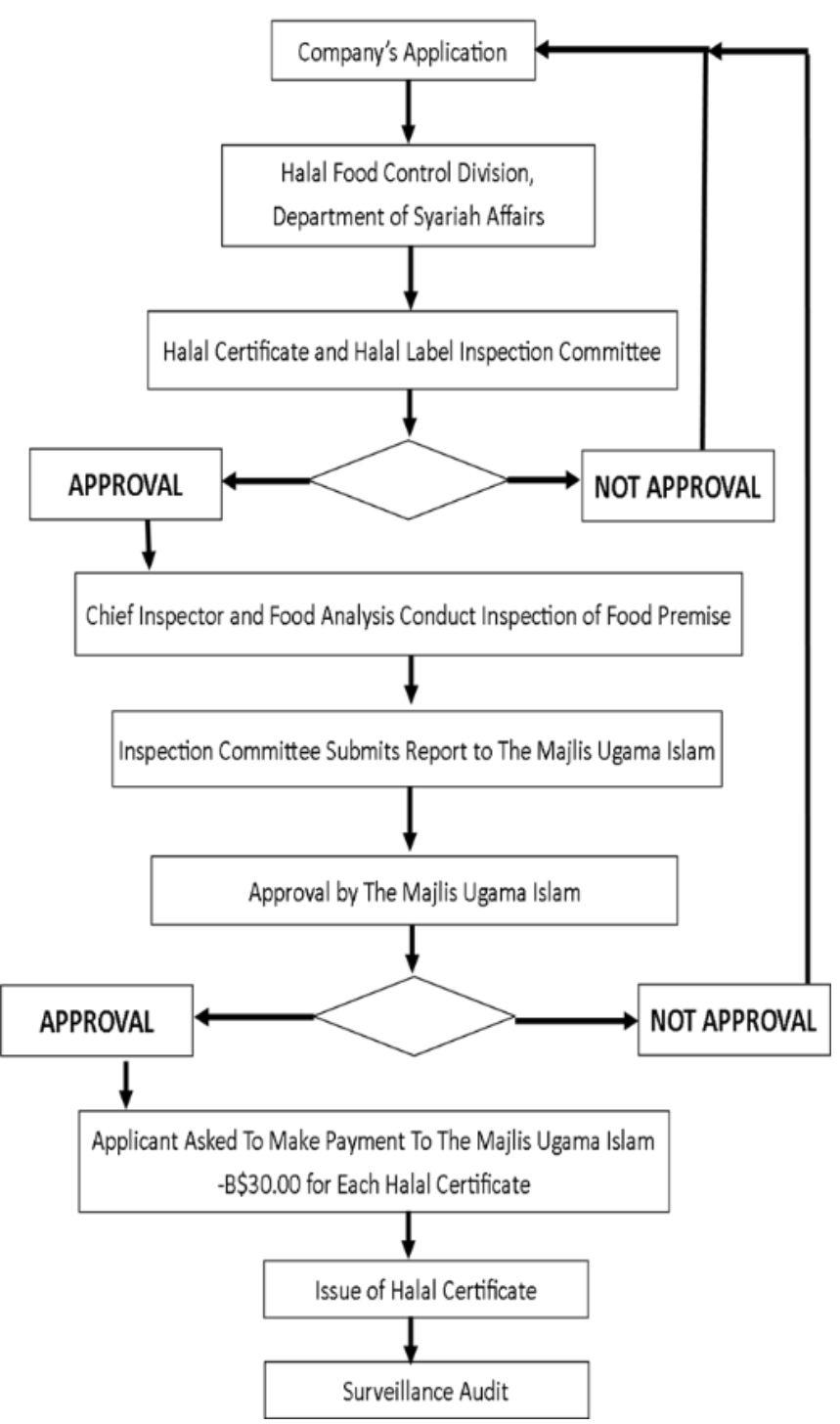

Figure 1: Flowchart for Application of Halal Certificate Source from Guideline and Halal Label Certification (BCG Halal 1)

\section{Actors}

According to Noordin, Md Noor, Hashim, and Samicho, (2009), the actor is referring to those who are participating in the halal certification process. These actors are responsible for the specific tasks, roles, and responsibilities outlined in Table 4 below in the halal certification process. 
Table 4

Actors of Halal certification process

\begin{tabular}{|c|c|}
\hline Actors & Responsibilities \\
\hline Administration Staff & $\begin{array}{l}\text { - Handling application form, supporting documents and } \\
\text { certificate fee }\end{array}$ \\
\hline Secretariat of Halal Certification (BKMH) & $\begin{array}{l}\text { - Halal Certification and Halal Label Inspection } \\
\text { Committee } \\
\text { - Examine and verify the application form and supporting } \\
\text { documents } \\
\text { - Issue Halal Certification }\end{array}$ \\
\hline Auditors & $\begin{array}{l}\text { - Examining the product ingredients based on technical } \\
\text { and shariah perspectives } \\
\text { - Premises inspection, } \\
\text { - Preparing inspection report, } \\
\text { - } \quad \text { Committee of Internal Pre-meeting Halal certification }\end{array}$ \\
\hline Inspection Committee & $\begin{array}{l}\text { - } \text { Committee of Internal Pre-meeting Halal certification } \\
\text { - } \quad \text { Pre-approval of Halal certification } \\
\text { - } \quad \text { Submits report/presenting halal applicants to MUIB }\end{array}$ \\
\hline Halal Certification Panels (MUIB) & $\begin{array}{l}\text { - Decision making in Halal certification } \\
\text { approval/rejection }\end{array}$ \\
\hline
\end{tabular}

\section{Information}

Sufficient information is significant to the halal certification process since the halal certification process could be hindered if there is insufficient information or documentation. Applicants should providw all the reliable information and supporting documents along with their application form. The document checklist for halal certification is shown in Figure 2. 


\title{
Dinar
}

Surnal \&konomi \& Q Xeuangan \$slam

Vol 8, No 2: Agustus 2021 24-34

https://journal.trunojoyo.ac.id/dinar/index

ISSN: 2460-9889 (Cetak)

DOI: https://doi.org/10.21107/dinar.v8i2.10814

ISSN: 2580-3565 (Online)

\author{
BAHAGIAN KAWAL.AN MAKANAN HALAI \\ JABATAN HAL EHWAL. SYARIAH \\ KEMENTERIAN HAL EHWAL IGAM \\ KEMENTERIAN HAL EHWAL LGAM \\ SENARAI SEMAK PERMOHONAN SIJIL HALAL/ PERMIT HALAL
}

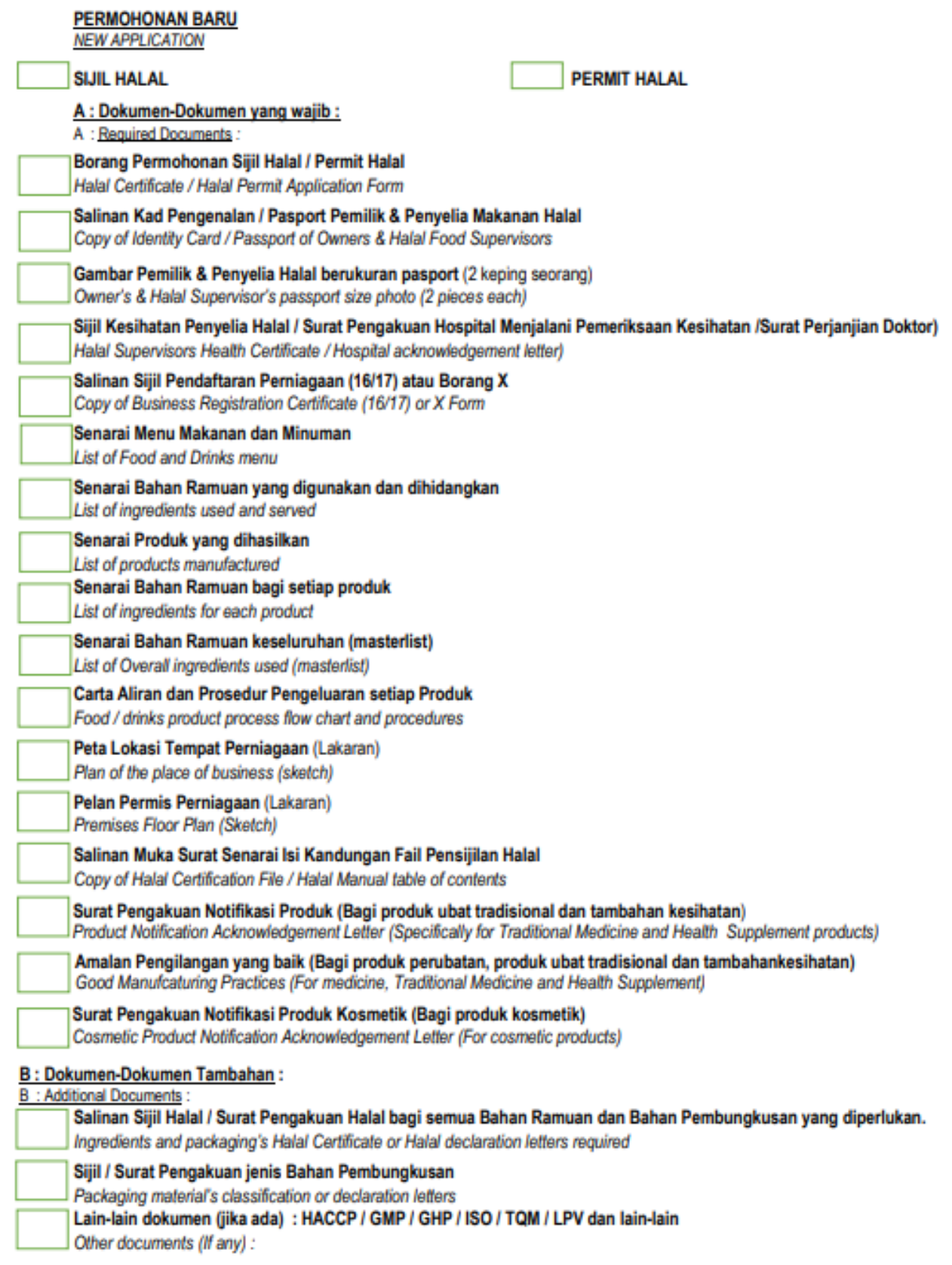

Figure 2 Document Checklist Required for Halal Certificate / Halal Permit Adapted from

http:// wmw.kheu.gov.bn/SitePages/Muat\%20Turun\%20Borang\%20Permohonan\%20Sijil\%20Halal $\% 20$ dan $\% 20$ Permit $\% 20$ Halal.aspx 


\section{Halal Certification Issues}

During the interview and observation at $\mathrm{BKMH}$, the issue that can be seen during the halal certification process is operational inefficiency. According to the Cambridge Dictionary, inefficiency is a situation in which someone or something fails to make effective use of resources such as time, materials, or labour (Cambridge Dictionary, 2020).

\section{Operational Inefficiency}

The BKMH cited the operational inefficiency of the halal certification process is due to 3 criterion (1) Applicants, (2) Internal Officers, and (3) Technology, which are tabulated in Table 5. The findings show that both parties' applicants and internal officers play vital roles to make the certification process goes smoothly with little help from technology.

\section{Table 5}

Operational Inefficiency

\begin{tabular}{|l|ll|}
\hline Criterion & \multicolumn{1}{c|}{ Operational Inefficiency } \\
\hline Applicants & $\begin{array}{l}\text { Halal certification applicants incompetency of completing the application forms due } \\
\text { to poor understanding of halal certification procedures }\end{array}$ \\
\hline $\begin{array}{l}\text { - Late issuance of halal certification due to late payments } \\
\text { Officers }\end{array}$ & \begin{tabular}{l} 
- $\begin{array}{l}\text { Limited manpower at certification bodies } \\
\text { Halal certification takes too long to be approved as halal panels meeting often being } \\
\text { postponed }\end{array}$ \\
\hline Technology
\end{tabular} & $\begin{array}{l}\text { Lack of technology used as the delivery of application form and filing system still } \\
\text { process manually }\end{array}$ \\
\hline
\end{tabular}

\section{Conclusion}

The study reveals (1) the halal certification value chain, (2) the related agencies and acts of the halal certification process, and (3) the information required in applying halal certification in Brunei Darussalam. The study also finds the issue arises during the halal certification process. Therefore this finding is very important for Brunei Darussalam as it may help related agencies and actors to improve their operational efficiency in the halal certification process. Further research may reuse and extend the finding on this paper and expand research to the different contexts of the research area.

\section{Acknowledgements}

This article is one of the results of the Research Grant entitled "Keberkesanan Proses Pensijilan Halal menurut Perspektif Masyarakat di Brunei Darussalam" which is supported by Universiti Islam Sultan Sharif Ali, Brunei Darussalam. In addition, the authors also wish to thank Bahagian Kawalan Makanan Halal for their invaluable contribution and feedback during the conduct of this research. 


\section{Vol 8, No 2: Agustus 2021 24-34 \\ ISSN: 2460-9889 (Cetak) \\ ISSN: 2580-3565 (Online)}

https://journal.trunojoyo.ac.id/dinar/index

DOI: https://doi.org/10.21107/dinar.v8i2.10814

\section{References}

Ab. Rahman, L. (n.d.). Shariah \& Malaysian Halal Certification System. Jurnal Penyelidikan Islam, 15-36.

Asa, R. S. (2019). An Overview of the Developments of Halal Certification Laws in Malaysia, Singapore, Brunei and Indonesia. Jurnal Syariah, 27(1), 173-200.

Cambridge Dictionary. (2020). Meaning of inefficiency in English. Retrieved November 7, 2020, from Cambridge Dictionary: https://dictionary.cambridge.org/dictionary/english/inefficiency

Haji Abdul Rahman, S. (2009). Industri Makanan Negara berorientasikan Islam. Jurnal Beriga, 103, 13-27.

Haji Kifli, H. (2019). Halal Certification in Brunei. In Lian Kwen Fee, \& F. M. Franco (Eds.), Institute of Asian Studies: Working Paper Series. Bandar Seri Begawan: Institute of Asian Studies, Universiti Brunei Darussalam.

Haji Sulaiman, N. (2018, Julai - Disember). Industri Halal ke Arah Menjana Kestabilan Ekonomi Sejajar dengan Wawasan Brunei 2035. Jurnal Beriga, 121, 19- 35.

Haji Sulaiman, N. (2019). Inisiatif Pihak Berkepentingan dalam Pembangunan Industri Halal di Brunei Darussalam. Jurnal Beriga, 123, 55-73.

Haji Sulaiman, N. (2020). Halal Sustainability: A Strategic Roadmapping for Brunei Darussalam. 4th International Seminar Halalan Thayyiban Products and Services 2019 (pp. 286-302). Bandar Seri Begawan: UNISSA Press.

Mohd Raffi, R. (2020). An Overview of Halal Industry of Brunei Darussalam. In R. Setyowati, N. Deuraseh, \& N. Sulaiman (Eds.), Basic Themes toward Halal Sustainability Management in Brunei Darussalam and Indonesia (pp. 97-106). Semarang: Yoga Pratama.

Noordin, N., Md Noor , N., \& Samicho, Z. (2014). Strategic Approach to Halal Certification System: An Ecosystem Perspective. Procedia-Social Behavioral Sciences, 121, 79-95. doi:10.1016/j.sbspro.2014.01.1110

Noordin, N., Md Noor, N., Hashim, M., \& Samicho, Z. (2009). Value Chain of Halal Certification: A Case Study of the Malaysia Halal Industry. European and Mediterranean Conference on Information Systems 2009 (EMCIS2009), (pp. 1-14). Izmir.

Othman, N., Miskam, S., Ab. Hamid, N., Syed Ager, S., Abdullah, M., Mohd. Shahwahid, F., . . Saidpudin, W. (2015). Pensijilan Makanan Halal di Brunei Darussalam. World Academic and Research Congress 2015 (World-AR 2015) (pp. 59-68). Jakarta: YARSI University.

Porter, M. (1985). Competitive Advantage Creating and Sustaining Superior Performance. New York: Free Press.

Riaz, M., \& Chaudry, M. (2004). Halal Food Production. Boca Raton, FL: CRC Press.

Saidpudin, W., Abd Hamid, N., Othman, N., Miskam, S., Abd. Wahab, N., Mohd Shahwahid, F., . . \& \& Marliana, A. (2015). Pensijilan Halal di Rantau Asia: Malaysia, Brunei, Indonesia dan Thailand. World Academic and Research Congress 2015 (WORLD AR-2015) (pp. 5-24). Jakarta: YARSI University. 